\title{
Enhancing the In Vitro Biological Activity of Degraded Silk Sericin and Its Analog Metabolites
}

\author{
Zhen-Zhen Wei, Yu-Jie Weng and Yu-Qing Zhang *D
}

Citation: Wei, Z.-Z.; Weng, Y.-J.; Zhang, Y.-Q. Enhancing the In Vitro Biological Activity of Degraded Silk Sericin and Its Analog Metabolites. Biomolecules 2022, 12, 161. https:// doi.org/10.3390/biom12020161

Academic Editor: David E. Stec

Received: 17 December 2021

Accepted: 18 January 2022

Published: 19 January 2022

Publisher's Note: MDPI stays neutral with regard to jurisdictional claims in published maps and institutional affiliations.

Copyright: (c) 2022 by the authors. Licensee MDPI, Basel, Switzerland. This article is an open access article distributed under the terms and conditions of the Creative Commons Attribution (CC BY) license (https:// creativecommons.org/licenses/by/ $4.0 /)$.

\author{
School of Biology and Basic Medical Sciences, Medical College, Soochow University, RM702-2303, No. 199, \\ Renai Road, Industrial Park, Suzhou 215123, China; 20204021006@stu.suda.edu.cn (Z.-Z.W.); \\ 20184021002@stu.suda.edu.cn (Y.-J.W.) \\ * Correspondence: sericult@suda.edu.cn
}

\begin{abstract}
Two sericins of high and low molecular weight (HS and LS) were prepared from commercial silkworm cocoon silk with a boiling water and $\mathrm{Ca}(\mathrm{OH})_{2}$ solution with ultrasonic treatments, respectively. This study first investigated the release concentration of the two abovementioned sericins in simulated saliva, gastric juice, and intestinal juice ( $\mathrm{pH} 6.8,2.0$, and 7.4, respectively) within $10 \mathrm{~h}$. The results showed that the order of sericin release rate and its amount in the simulated environment was gastric juice > saliva > intestinal juice. Second, the molecular weights of both sericin metabolites formed by in vitro enzymatic degradation were lower than $15 \mathrm{kDa}$. The $\alpha$-glucosidase inhibitory activities of both sericins and their analog metabolites were positively correlated with their concentrations. The $\mathrm{IC}_{50}$ values of the HS- and LS-derived metabolites were $1.02 \pm 0.12 \mathrm{mg} / \mathrm{mL}$ and $0.91 \pm 0.15 \mathrm{mg} / \mathrm{mL}$, respectively, which were five to seven times lower than those of both original sericins. The total antioxidant capacities and hydroxyl radical scavenging capacities of both metabolites were enhanced by one- to three-fold compared with HS and LS. These results indicate that both sericins, regardless of molecular size, have significantly enhanced antioxidant, superoxide free radical scavenging, and glycosidase inhibitory activities after simulated metabolism, and that LS is better than HS regardless of simulated digestion. These results confirm that sericin is important in the sustainable development and utilization of silk resources, especially the reduction in environmental pollution, and provides new ideas for the development of adjuvant treatments for diabetes and the development of foods with anti-hyperglycemic functions.
\end{abstract}

Keywords: sericin; calcium hydroxide; ultrasonic degumming; antioxidant; lowering blood sugar

\section{Background}

Since 2010, the annual output of silkworm cocoons in China alone has exceeded 600,000 tons, accounting for about $70 \%$ of the total global output. During the production of cocoon silk, about 40,000 to 50,000 tons of sericin globally are discharged in alkaline liquid waste every year. This not only causes serious environmental pollution and poor water quality, but also wastes a considerable amount of natural protein resources [1,2]. Therefore, cleaner processing technology and the functional development of sericin can not only lead to new uses for it, but more importantly, can reduce the level of environmental pollution caused by the degumming and degradation of this protein [3].

Sericin usually adheres to the outer layer of silk fiber. The main methods for separating and purifying sericin are high-temperature hydrolysis [4], high-temperature hydrolysis in an alkaline salt solution [5], acid extraction [6], protease degumming [7], neutral soap degumming [8], high-temperature and high-pressure degumming [9], and other degumming methods. Most commonly used in the laboratory are the solvent method, physical method, and biological enzymatic method. Alkaline solutions such as sodium hydroxide and sodium carbonate are the most commonly used solvents at present. However, it is difficult to separate these from sericin because the sodium salt formed later is easily soluble 
in water. The method developed in this laboratory using $\mathrm{Ca}(\mathrm{OH})_{2}$ aqueous solution as a degumming agent can completely remove sericin from silk fibers without destroying the mechanical properties of silk fibers. After being neutralized with acid, it can form insoluble precipitates. It can also form calcium sulfate precipitates upon reacting with sulfuric acid. Sericin can be used in plant fertilizers or building fillers without causing additional pollution [10]. Thus, this method of sericin separation is green and clean. We also found that the sericin obtained by the $\mathrm{Ca}(\mathrm{OH})_{2}$ degumming method has a lower molecular weight and higher in vitro antioxidant capacity, ultraviolet (UV) resistance, and inhibitory activity against $\alpha$-glycosidase [11].

The large number of polar groups in sericin and their special structure result in it having several different biological properties. In different extraction processes, the peptide chain of sericin is broken to different degrees, producing different lengths of polypeptides, and thus exhibiting biological characteristics, such as antioxidant activity $[12,13]$, the capacity to lower blood sugar [14], and anti-UV [15,16], anti-aging [17,18], antibacterial $[19,20]$ and other in vitro properties. We used different methods to separate sericin, and obtained and compared the composition of outer sericin, inner sericin, and whole sericin in white commercial cocoons, and found that the three sericins contained serine (Ser), aspartic acid (Asn), and glycine (Gly), in quantities accounting for more than 50\% of their total amino acids [21]. All three types of sericin exhibited obvious anti-UV activity. Among them, low-molecular-weight sericin peptides are more easily absorbed and utilized by the human body and have the potential to be used as raw materials for cosmetics. Amino acid analysis of an alcoholic extract of green cocoon sericin also led to similar conclusions. Ser, Asn, Gly, and proline (Pro) accounted for the largest proportion of amino acids in the alcoholic extract of green cocoon sericin, i.e., $46.98 \%$ of the total amino acid content. Testing with the 1,2'-azino-bis(3-ethylbenzthiazoline-6-sulphonic acid (ABTS) and FRAP methods showed that the antioxidant capacity of the four extracts was in the order: alcohol extract of green cocoon silk $>$ outer sericin $>$ whole sericin $>$ inner sericin. In addition, the inhibition rate of outer-layered sericin $(20 \mathrm{mg} / \mathrm{mL})$ on $E$. coli could reach $50 \%$. The $\mathrm{IC}_{50}$ values of tyrosinase inhibitory activity of outer sericin and whole sericin were $8.67 \mathrm{mg} / \mathrm{mL}$ and $3.49 \mathrm{mg} / \mathrm{mL}$, respectively. The $\alpha$-glucosidase inhibition rates of $10 \mathrm{mg} / \mathrm{mL}$ outer sericin and whole sericin reached $65.62 \%$ and $51.3 \%$, respectively [22,23]. These results show that although these three sericins have some differences in physical and chemical properties, they all have obvious antioxidant, anti-UV, anti-bacterial, moisture absorption, and whitening properties, and can lower blood sugar levels in vitro. However, these results were all obtained via in vitro evaluation experiments. Thus far, there are no reports on in vitro evaluation experiments on simulated digestion products of degraded sericin. Therefore, this study simulated the digestion of high- and low-molecular-weight sericin in saliva, gastric juice, and intestinal fluid to explore the antioxidant properties, free radical scavenging ability, and in vitro antidiabetic activity of the digested products.

\section{Materials and Methods}

\subsection{Materials}

Commercial white cocoons (So-hao $\times$ Zhong-Ye) were purchased from Nantong New Silk Road Silk Co., Ltd. (Jiangsu, China); $\alpha$-amylase (activity $\geq 50 \mathrm{U}$ ), pepsin (purity: 99\%), trypsin ( $\geq 250$ units $/ \mathrm{mg}$ ), the BCA protein content detection kit and other reagents were purchased from Sigma Co., Ltd.

\subsection{Sericin Sample Preparation}

An appropriate amount of cocoon shells was weighed, $90 \times$ distilled water $(W / V)$ was added, and ultrasonic treatment was carried out at $100{ }^{\circ} \mathrm{C}$ for $2 \mathrm{~h}$ at an ultrasonic power of $600 \mathrm{~W}$. The distilled water was replaced, and the above treatment was repeated once. The degumming liquid was collected and concentrated to an appropriate volume under negative pressure. The liquid was centrifuged at 10,000 rpm for $30 \mathrm{~min}$ to remove insoluble impurities, the supernatant was collected and concentrated again, and the concentrated 
solution was dried using a spray dryer to form a powdered sample with a higher molecular weight of sericin (HS).

A certain amount of cocoon shell was weighed and added to $0.025 \%(W / V) \mathrm{Ca}(\mathrm{OH})_{2}$ solution at a bath ratio $(1: 90, \mathrm{~W} / \mathrm{V})$ [24]. Ultrasonic treatment was carried out at $100{ }^{\circ} \mathrm{C}$ for $2 \mathrm{~h}$ and boiling degumming was performed for $4 \mathrm{~h}$ at an ultrasonic power of $600 \mathrm{~W}$. The $\mathrm{Ca}(\mathrm{OH})_{2}$ solution was replaced with fresh solution and the degumming was repeated once. The degumming liquid was collected and concentrated to an appropriate volume under negative pressure. The $\mathrm{pH}$ was adjusted to neutral with $1 \mathrm{~mol} / \mathrm{L}$ sulfuric acid and the sample was left to stand for $12 \mathrm{~h}$ at $4{ }^{\circ} \mathrm{C}$, then centrifuged at 10,000 rpm for $30 \mathrm{~min}$ to remove precipitated calcium sulfate and other insoluble impurities. The supernatant was collected and concentrated again. A powdered sample with a lower molecular weight of sericin (LS) was obtained using a spray dryer.

\subsection{Preparation of Simulated Digestion Products}

The two above-mentioned sericins (HS and LS) were diluted with distilled water to an appropriate concentration $(10 \mathrm{mg} / \mathrm{mL})$, and $18 \mathrm{~mL}$ of each was taken for later use. Then, $2 \mathrm{~mL} \alpha$-amylase was added to $18 \mathrm{~mL}$ sample solution and incubated at $37^{\circ} \mathrm{C}$ for $10 \mathrm{~min}$, following which the $\mathrm{pH}$ was adjusted to $2.0 \pm 0.1$ with $1 \mathrm{~mol} / \mathrm{L}$ hydrochloric acid (three samples were taken, $1.0 \mathrm{~mL}$ for each sample, which was the $\mathrm{A}_{10}$ sample). Thereafter, $2 \mathrm{~mL}$ pepsin was added, the solution was incubated at $37^{\circ} \mathrm{C}$ for $90 \mathrm{~min}$, and the $\mathrm{pH}$ was adjusted to $7.0 \pm 0.1$ with $1.0 \mathrm{~mol} / \mathrm{L} \mathrm{NaOH}$ solution (three samples were taken, $1 \mathrm{~mL}$ each, which was the $\mathrm{B}_{90}$ sample). After adding $5 \mathrm{~mL}$ trypsin and $5 \mathrm{~mL}$ sodium cholate solution, the mixture was incubated at $37^{\circ} \mathrm{C}$ for $90 \mathrm{~min}$ and the enzyme was inactivated using a water bath at $90-95{ }^{\circ} \mathrm{C}$ (three samples, $1.0 \mathrm{~mL}$ for each sample, were $\mathrm{C}_{90}$ samples). The concentrations of sericin in the HS and LS digestion products (EHS and ELS) were detected with the BCA detection kit.

\subsection{In Vitro Simulated Sustained Release}

The simulated digestion experiments of two sericin proteins were carried out according to the previously reported methods and procedures, with slight modifications [25,26]. HS and LS solutions each with a concentration of $10 \mathrm{mg} / \mathrm{mL}$ were put into a dialysis bag (molecular weight $1 \mathrm{kDa}$ ), sealed with a thin thread, and immersed in $10 \mathrm{~mL}$ of different buffers containing Tween 80 . The three buffers of different $\mathrm{pH}$ value $(2.0,6.8$, and 7.4$)$ simulated gastric juice, intestinal juice, and blood, respectively. The samples were fixed in a constant temperature shaker at $37^{\circ} \mathrm{C}$ and rotated at a speed of $100 \mathrm{rpm}$ for $0.5,1,2,4,6,8$, 10 , and $12 \mathrm{~h}$. The same volume of buffer solution was a control, the BCA method was used to determine the total protein content in the dialysis bag sustained-release sample, and the slow-release curves of the two sericins were plotted. The experiment was set up in three parallel groups. These sustained-release sericin samples simulated in vitro are referred to as EHS or ELS.

\subsection{Determination of Molecular Weight Range}

The molecular weight range of four proteins (HS, LS, EHS, and ELS) was determined by SDS-PAGE, according to the method previously reported by the author [27].

\subsection{Determination of $\alpha$-Glucosidase Inhibitory Activity}

HS, LS, EHS, and ELS samples were prepared as protein solutions of a given concentration. The $\alpha$-glucosidase inhibitory activity was determined by enzymatic reaction according to the method previously reported by the author [28].

\subsection{Determination of $\alpha$-Amylase Inhibitory Activity}

Precisely $40 \mu \mathrm{L}$ of the above four sample solutions was taken in tubes, $40 \mu \mathrm{L}$ of $0.02 \mathrm{U} / \mathrm{mL}$ amylase was added, and samples were incubated in a $37^{\circ} \mathrm{C}$ water bath for $10 \mathrm{~min}$. Once again, $40 \mu \mathrm{L}$ amylose solution was added and incubated in a $37^{\circ} \mathrm{C}$ water 
bath for $10 \mathrm{~min}$, following which $20 \mu \mathrm{L}$ of $1 \mathrm{~mol} / \mathrm{L}$ hydrochloric acid was added to stop the reaction. Then, $50 \mu \mathrm{L}$ colorimetric iodine solution was added and the absorbance at $620 \mathrm{~nm}$ was measured and recorded as A. With PBS as a blank control, the above steps were repeated. The absorbance value at $620 \mathrm{~nm}$ was $\mathrm{A}_{0}$, and the experiment was conducted on three groups in parallel. Calculation formula: $\alpha$-amylase inhibitory activity $(\%)=\left(1-\mathrm{A} / \mathrm{A}_{0}\right) \times 100$.

\subsection{Determination of ABTS and Hydroxyl Radical Scavenging Rate}

The ABTS method used in this study is an indirect method to detect the antioxidant capacity of substances. Oxidized ABTS is a stable blue-green cationic ABTS ${ }^{+}$radical, soluble in acidic ethanol or aqueous phase, with an absorption maximum detected at $734 \mathrm{~nm}$. After $\mathrm{ABTS}^{+}$was added to the solution to be tested, the antioxidant component reacted with $\mathrm{ABTS}^{+}$and then faded. At this time, the change in absorbance at $734 \mathrm{~nm}$ was detected. Trolox was used as a control system to quantify the antioxidant capacity of the solution to be tested [29]. The scavenging activity of $\mathrm{HO} \cdot$ was determined according to a previously described method [30].

\subsection{Statistics}

The experimental data are expressed as the mean \pm standard deviation (SD). Significant differences between two sets of data were assessed using one-way ANOVA (Origin version 8.5$)$. A $p$-value $<0.05$ was considered statistically significant.

\section{Results}

\subsection{In Vitro Simulated Sustained Release}

In order to investigate the drug accumulation effect of sericin in different organs, this experiment utilized the dialysis bag method to determine the cumulative concentrations of two sericins (HS and LS) in simulated saliva, gastric juice, and intestinal juice ( $\mathrm{pH} 6.8$, 2.0, and 7.4, respectively) within $12 \mathrm{~h}$. As shown in Figure 1, the sericin accumulation rate is related to the types of sericin and digestive juice. Regarding the sericin type, the accumulation speeds and concentrations of LS in the three simulated digestive juices were higher than those of HS. In comparison with the cumulative effect of both sericins in different simulated digestive juices, the accumulation speed and amount of sericin in simulated gastric juice were the highest, followed by simulated saliva and then simulated intestinal juice.

\subsection{Molecular Weight Range of Sericin}

In order to explore the differences in the molecular weight of sericin obtained by different degumming methods before and after simulated digestion in vitro, the molecular weight ranges of four sericins were determined by SDS-PAGE. As shown in Figure 2, the molecular weight range of the four powdered sericins was ordered as follows: ELS < EHS $<$ LS $<$ HS. HS had the largest range of molecular weight and a relatively concentrated distribution. The electrophoresis bands were mainly concentrated in the $15-50 \mathrm{kDa}$ range, indicating that the degradation effect of boiling water combined with ultrasound on sericin is relatively small. The band color of LS was relatively light, but its molecular weight distribution was the widest, which indicates that most sericin peptides were degraded into smaller peptides and amino acids. The molecular weight distribution of sericin peptides obtained by silk degumming in $0.025 \%$ calcium hydroxide aqueous solution was concentrated below $20 \mathrm{kDa}$ [22]. It also indicates that the $0.025 \% \mathrm{Ca}(\mathrm{OH})_{2}$ solution has a better degradation effect on sericin. The molecular weight distribution range of EHS was much smaller than that of HS, and the electrophoresis bands were mainly concentrated below $15 \mathrm{kDa}$. The color of the ELS bands was lightest, and it mainly concentrated below $15 \mathrm{kDa}$, which also shows that its range of molecular weight is the smallest. EHS and ELS showed no obvious traces in the molecular weight range of $15-50 \mathrm{kDa}$. This shows that 
HS and LS are effectively decomposed into low-molecular-weight peptides and hydrolates after simulated digestion in vitro.
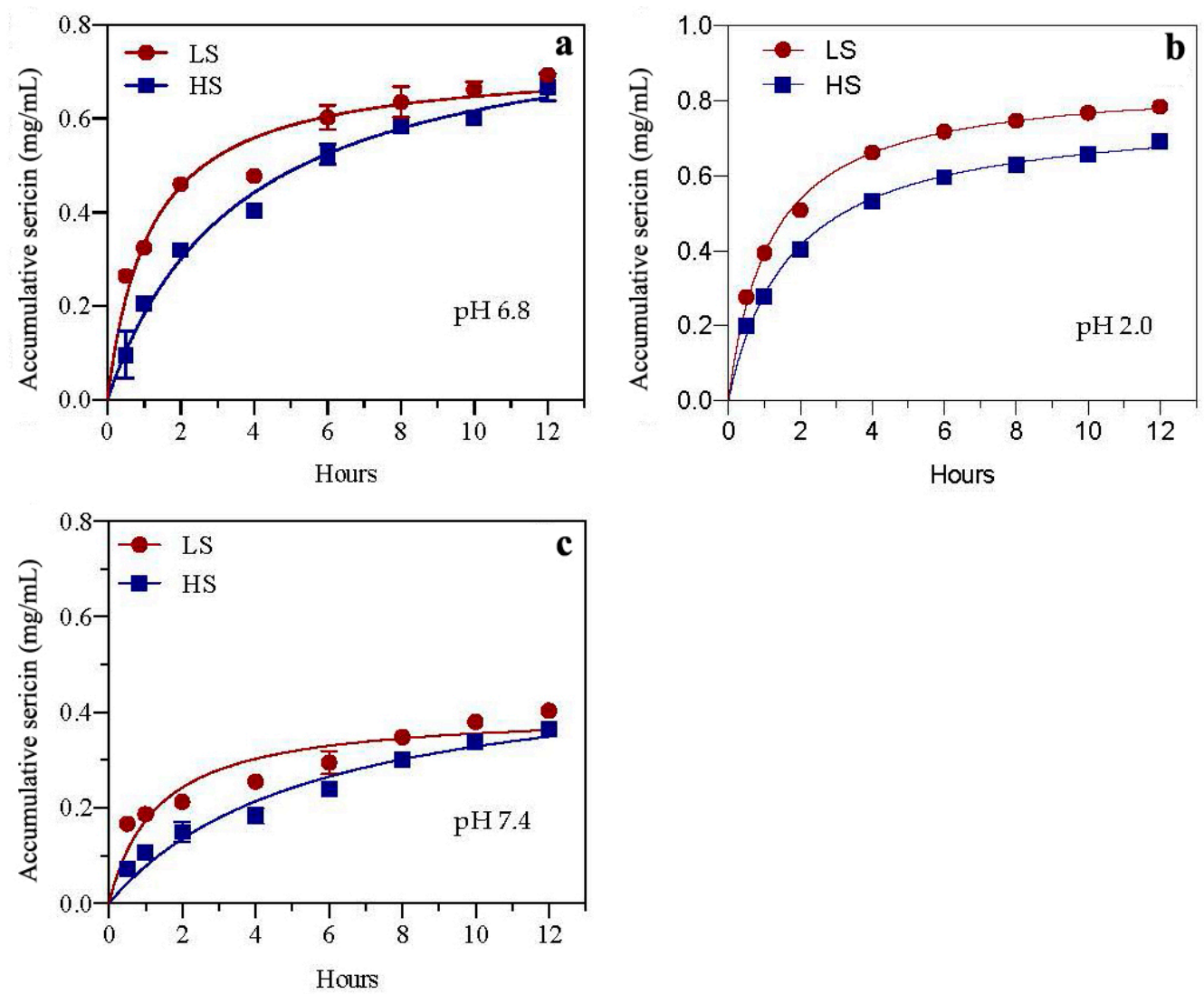

Figure 1. Drug accumulation rates of two sericin peptides in simulated digestive juices $\mathrm{pH} 6.8$ (a), pH 2.0 (b) and pH 7.4 (c) in vitro. HS and LS: higher and lower molecular weight sericin, respectively; EHS and ELS: enzymatic digestion products of HS and LS, respectively.

\section{Marker1 HS EHS ELS LS Marker2 kDa}

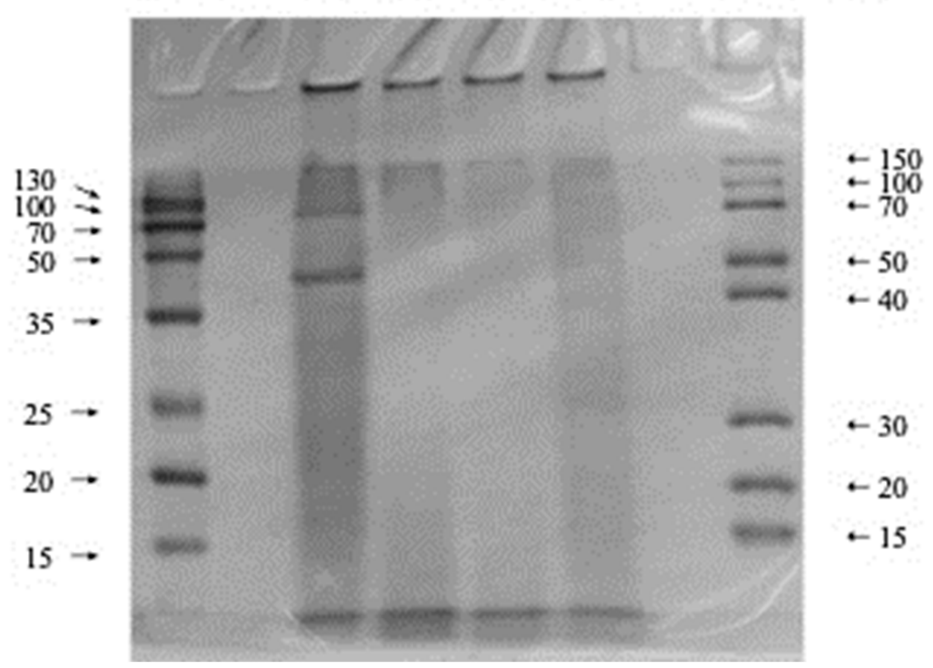

Figure 2. SDS-PAGE (15\% gel) of sericin peptides and their digestive metabolites. HS and LS: higher and lower molecular weight sericin, respectively; EHS and ELS: enzymatic digestion products of HS and LS, respectively. 


\section{3. $\alpha$-Glucosidase Inhibitory Activity}

$\alpha$-Glucosidase can dissociate polysaccharides into monosaccharides, which mainly exist in the mucosa of the small intestine, and is essential for the sugar metabolism pathway. If its activity is inhibited, the catabolism of carbohydrates is inhibited, thereby reducing blood sugar levels. After the experimental data was fitted and analyzed by the software Origin 8.5, as shown in Figure 3a, in the range of $1.0-10 \mathrm{mg} / \mathrm{mL}$, the concentration of HS and its ability to inhibit the activity of $\alpha$-glucosidase were dose-dependent, and its $\mathrm{IC}_{50}$ was $5.64 \pm 0.22 \mathrm{mg} / \mathrm{mL}$, a relatively low concentration of HS showed a good inhibitory effect on $\alpha$-glucosidase activity. As shown in Figure $3 b$, LS concentration and $\alpha$-glucosidase activity inhibited $\mathrm{IC}_{50}$ was $4.83 \pm 0.23 \mathrm{mg} / \mathrm{mL}$. After $\mathrm{HS}$ was subjected to mock digestion, the $\mathrm{IC}_{50}$ of EHS concentration and glucosidase inhibitory activity was $1.02 \pm 0.12 \mathrm{mg} / \mathrm{mL}$. $\mathrm{IC}_{50}$ of ELS concentration and glucosidase inhibitory activity was $0.91 \pm 0.15 \mathrm{mg} / \mathrm{mL}$. After simulated metabolism in vitro, both HS and LS could more effectively inhibit the degradation of carbohydrates, which is expected to reduce the blood glucose level in the body.

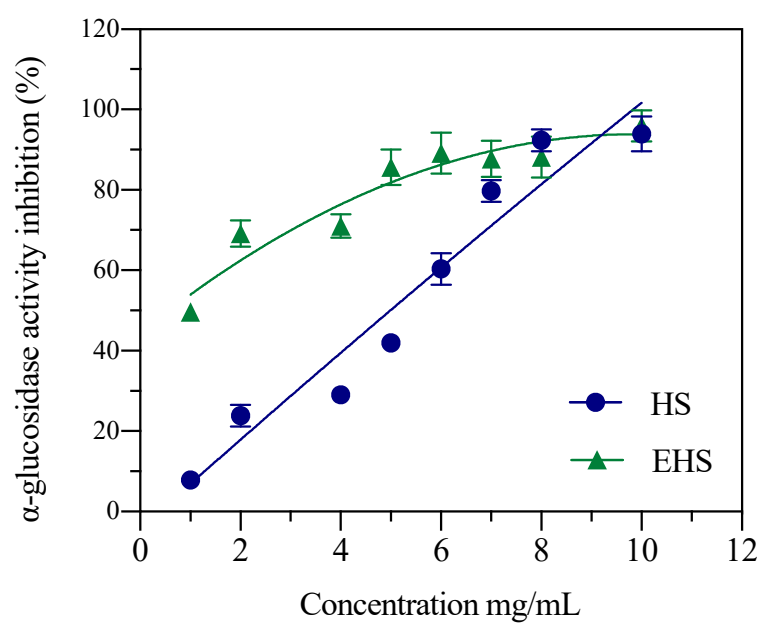

(a)

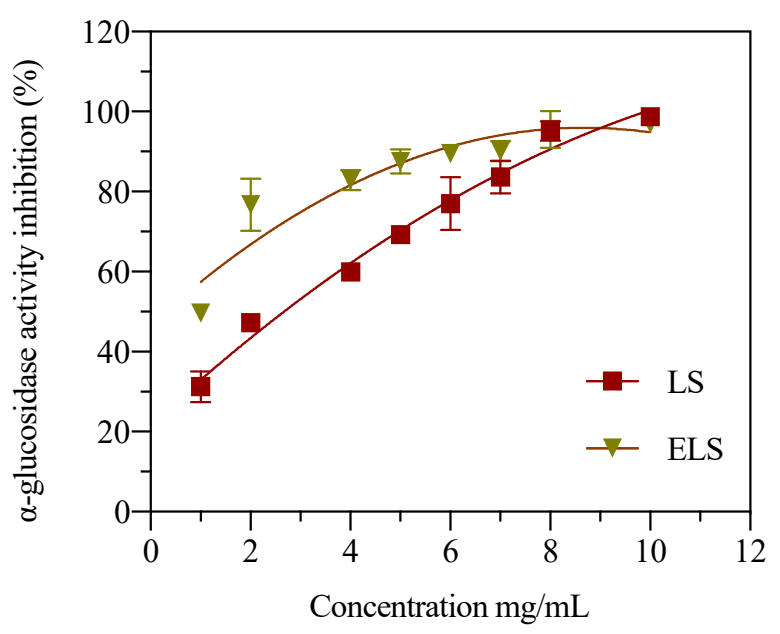

(b)

Figure 3. The inhibition activities of both HS (a) and LS (b) and their enzymatic metabolites on $\alpha$-glucosidase. HS and LS: higher and lower molecular weight sericin, respectively; EHS and ELS: enzymatic digestion products of HS and LS, respectively.

\section{4. $\alpha$-Amylase Inhibitory Activity}

$\alpha$-Amylase can attack the $\alpha-1,4$-glycosidic bond of starch to form reducing sugars, mainly trisaccharides; thus, it can reduce the viscosity of starch and is also called a liquefaction enzyme. After fitting and analyzing the experimental data by the software Origin 8.5 , as shown in Figure $4 \mathrm{a}$, in the range of $0.1-1 \mathrm{mg} / \mathrm{mL}$, the concentration of HS was dosedependent with the inhibition of $\alpha$-amylase. When the concentration was $1.05 \mathrm{mg} / \mathrm{mL}$, the highest inhibition rate was $40.65 \%$, and the $\mathrm{IC}_{50}$ between EHS concentration and $\alpha$ amylase inhibitory activity was $0.37 \pm 0.02 \mathrm{mg} / \mathrm{m}$. Relatively low concentrations of HS showed a better inhibitory effect on $\alpha$-amylase activity. As shown in Figure $4 \mathrm{~b}$, when the LS concentration was $1 \mathrm{mg} / \mathrm{mL}$, the highest inhibition rate was $52.57 \%$, and the $\mathrm{IC}_{50}$ of ELS concentration and $\alpha$-amylase inhibitory activity was $0.28 \pm 0.05 \mathrm{mg} / \mathrm{mL}$. The above results indicate that after simulated metabolism in vitro, both HS and LS can more effectively inhibit starch hydrolysis, thereby exerting a hypoglycemic effect in the body. 


\subsection{Total Antioxidant Capacity}

$\mathrm{ABTS}^{+}$is blue-green in color. Antioxidant substances react with $\mathrm{ABTS}^{+}$to make solutions fade; therefore, the ABTS scavenging ability can be expressed by the absorbance value. In this study, the ABTS scavenging abilities of two sericins (HS and LS) at concentrations of $1-10 \mathrm{mg} / \mathrm{mL}$, and their degradation products (EHS and ELS) at $0.1-1.0 \mathrm{mg} / \mathrm{mL}$, were determined. After fitting and analyzing the experimental data by software Origin 8.5 , as shown in Figure 5, the scavenging ability of ABTS increased with the increase in sample concentration. The $\mathrm{IC}_{50}$ of HS concentration and ABTS clearance was $8.64 \pm 0.12 \mathrm{mg} / \mathrm{mL}$. The IC $\mathrm{I}_{50}$ of LS concentration and ABTS clearance was $6.79 \pm 0.07 \mathrm{mg} / \mathrm{mL}$. The $\mathrm{IC}_{50}$ of EHS concentration and ABTS clearance was $2.48 \pm 0.06 \mathrm{mg} / \mathrm{mL}$. The ABTS clearance $\mathrm{IC}_{50}$ of ELS was $2.72 \pm 0.04 \mathrm{mg} / \mathrm{mL}$. The experimental results showed that before the simulated digestion, the ABTS scavenging ability of LS was significantly higher than that of HS. After the simulated digestion, there were no significant differences in the ABTS scavenging abilities between the two products.

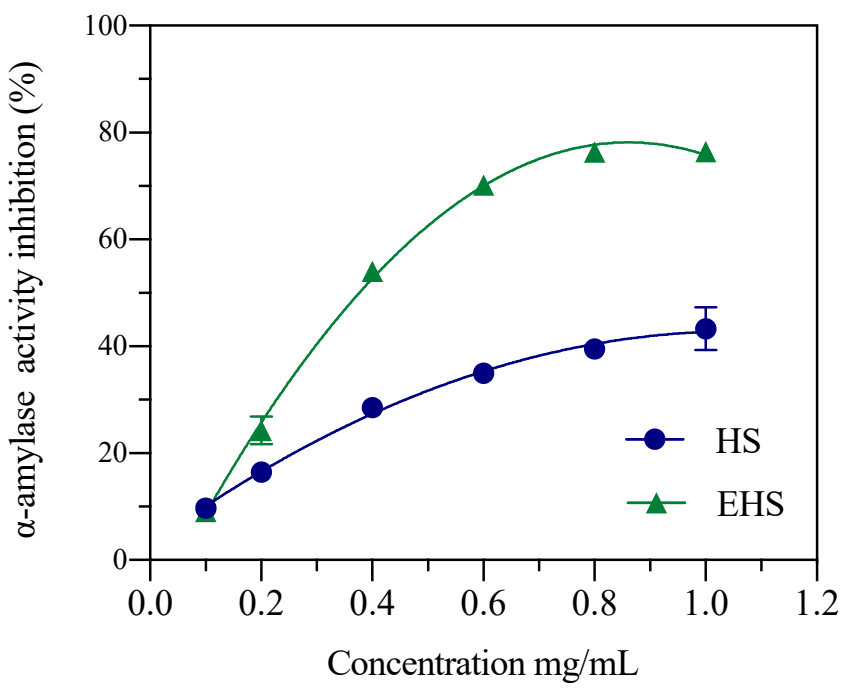

(a)

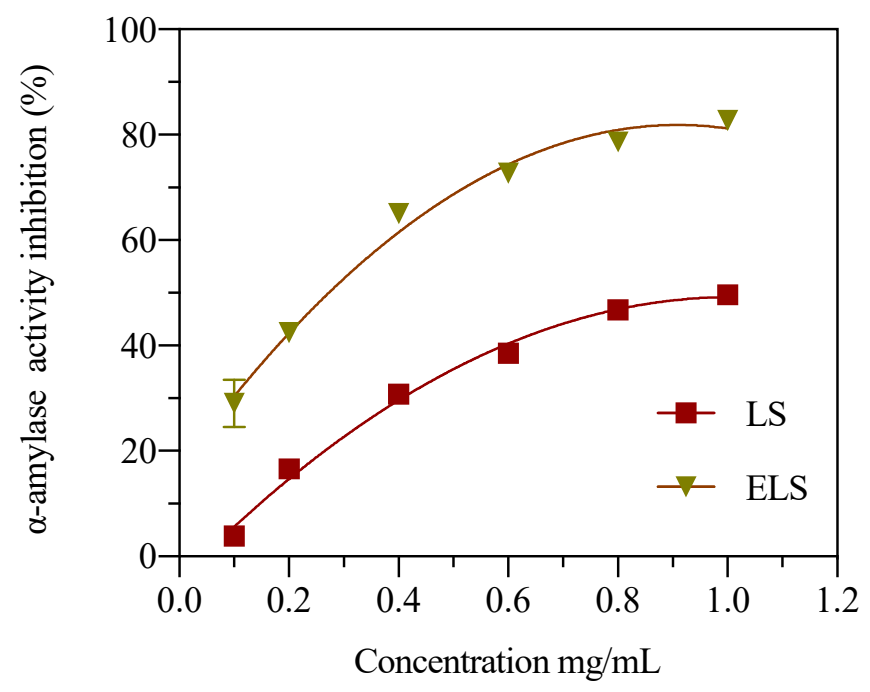

(b)

Figure 4. The inhibition activities of both HS (a) and LS (b) and their enzymatic metabolites on $\alpha$-amylase. HS and LS: higher and lower molecular weight sericin, respectively; EHS and ELS: enzymatic digestion products of HS and LS, respectively.

\subsection{Hydroxyl Radical Scavenging Capacity}

Hydroxyl free radicals $(\cdot \mathrm{OH})$ are the most active and toxic free radicals and can cause damage to cells. In vitro detection is mainly carried out with the Fenton reaction. Hydroxyl radicals react with salicylic acid to produce dihydroxybenzoic acid, which has an absorption peak at $510 \mathrm{~nm}$. When the components in a sample react with hydroxyl radicals, a change in absorbance is induced. Figure 6 shows that when the sericin concentrations were $1 \mathrm{mg} / \mathrm{mL}$ and $2 \mathrm{mg} / \mathrm{mL}$, the hydroxyl radical scavenging rate remained below $25 \%$, and when the concentration reached $6 \mathrm{mg} / \mathrm{mL}$, the hydroxyl free radical scavenging ability was significantly enhanced. After fitting and analyzing the data by Origin software, the IC50 of the hydroxyl radical scavenging rate of HS, LS, EHS and ELS were, respectively, $7.49 \pm 0.12 \mathrm{mg} / \mathrm{mL}, 6.33 \pm 0.12 \mathrm{mg} / \mathrm{mL}, 4.53 \pm 0.12 \mathrm{mg} / \mathrm{mL}, 3.25 \pm 0.12 \mathrm{mg} / \mathrm{mL}$, $0.12 \mathrm{mg} / \mathrm{mL}$. This figure shows that, regardless of the size of sericin molecules, they have a strong ability to scavenge hydroxyl radicals, their ability is stronger after digestion, and there is no significant difference between the two, whether they are digested or not. 


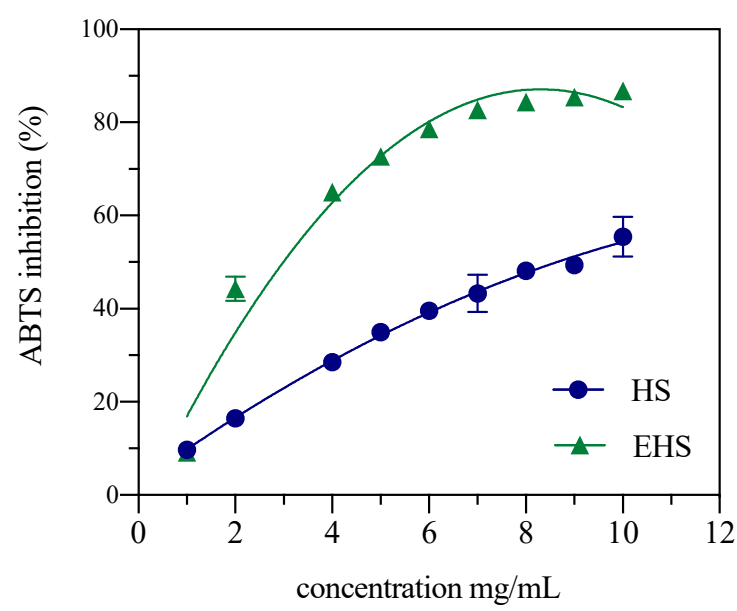

(a)

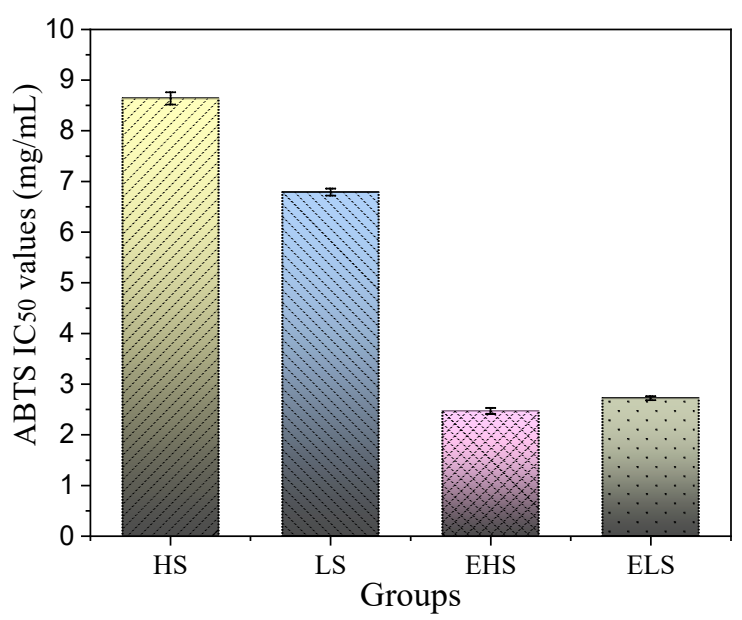

(c)

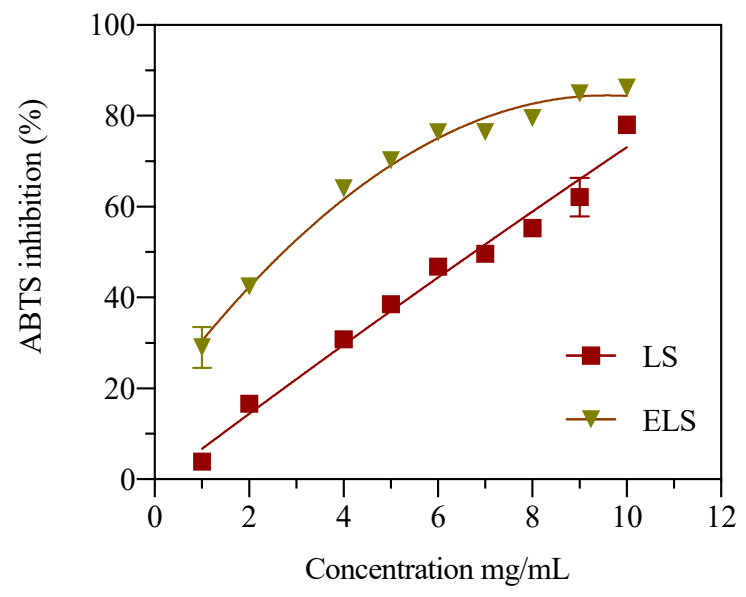

(b)

Figure 5. The ABTS scavenging ability of both peptides HS (a) and LS (b) and their enzymatic metabolites (c). HS and LS: higher and lower molecular weight sericin, respectively; EHS and ELS: enzymatic digestion products of HS and LS, respectively.

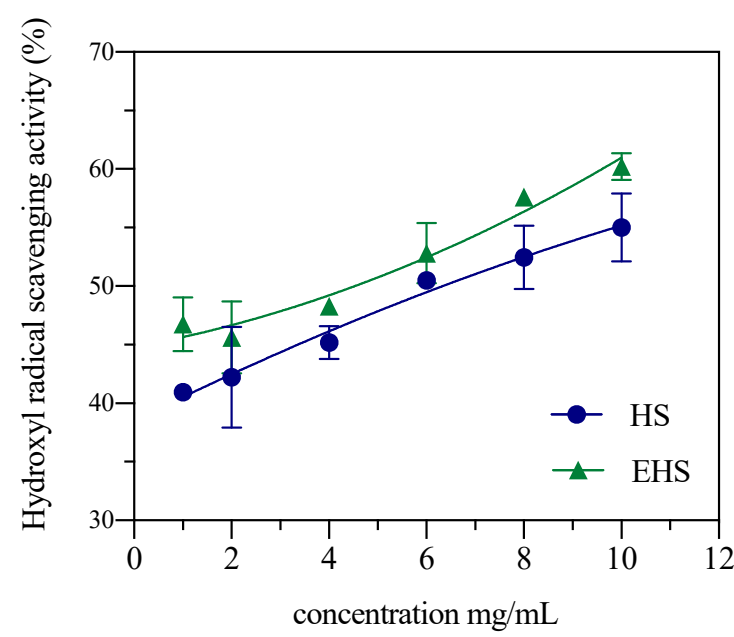

(a)

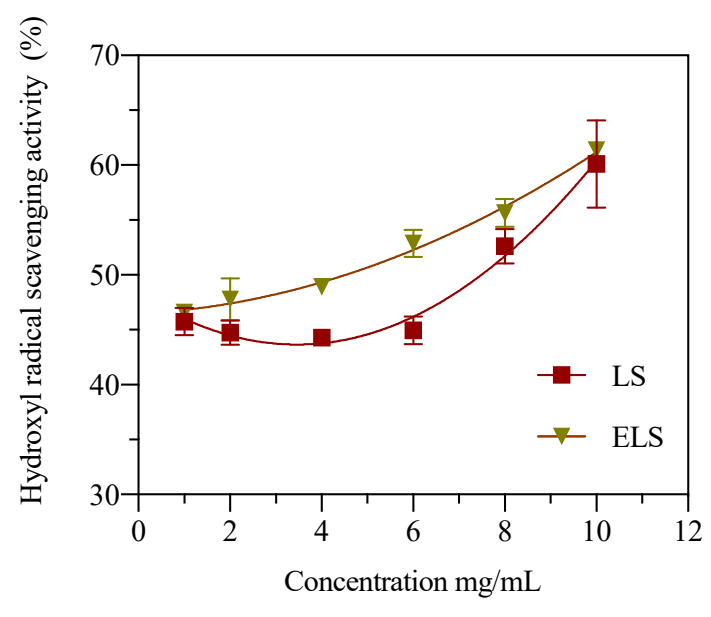

(b)

Figure 6. Cont. 


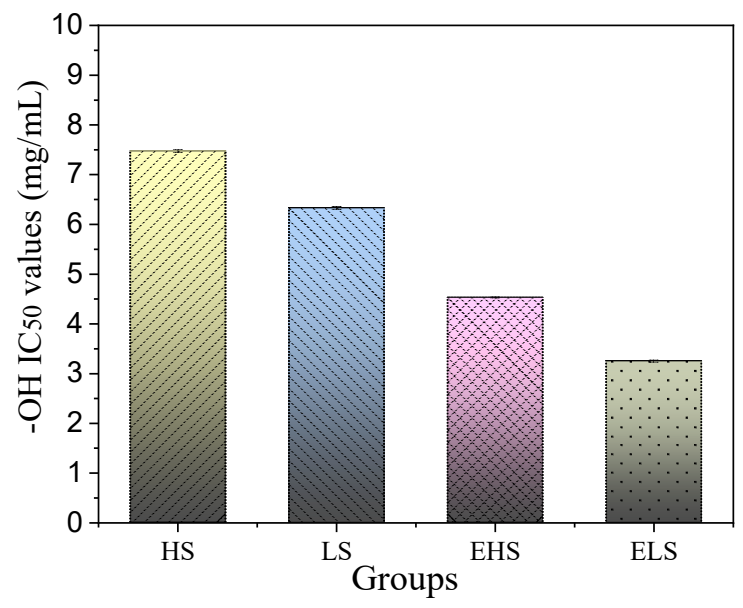

(c)

Figure 6. The hydroxyl radical scavenging activity of both sericins HS (a) and LS (b) and their digestive metabolites (c). HS and LS: higher and lower molecular weight sericin, respectively; EHS and ELS: enzymatic digestion products of HS and LS, respectively.

\section{Discussion}

In this study, a clean $\mathrm{Ca}(\mathrm{OH})_{2}$-ultrasonic method was used to obtain LS and a green high-temperature method was used to obtain HS. Researchers in the laboratory have reported the degumming rate, molecular weight range, and amino acid composition of LS; the degumming rate of the $\mathrm{Ca}(\mathrm{OH})_{2}$-ultrasonic method can reach $28.6 \%$ [22]. At the same time, the physical and chemical properties and in vitro biological activity of this lowmolecular-weight sericin peptide and its hydrolysate were also investigated and analyzed in detail [23]. The results show that the concentration of sericin that inhibits $\alpha$-glucosidase activity by $51.3 \%$ in vitro is $10 \mathrm{mg} / \mathrm{mL}$, which is also very close to the results of this experiment. In this experiment, the $\mathrm{IC}_{50}$ value of LS inhibition of $\alpha$-glucosidase activity was $6.83 \pm 0.23 \mathrm{mg} / \mathrm{mL}$. The $\mathrm{IC}_{50}$ value of the outer layer of HS prepared by the boiling method was slightly lower, at $5.64 \pm 0.22 \mathrm{mg} / \mathrm{mL}$. The $\mathrm{IC}_{50}$ values of their metabolites, ELS and EHS, were $0.91 \pm 0.15 \mathrm{mg} / \mathrm{mL}$ and $1.02 \pm 0.12 \mathrm{mg} / \mathrm{mL}$, respectively, and the $\mathrm{IC}_{50}$ values were significantly reduced by about five-fold. The $\alpha$-amylase inhibitory activities of LS and HS sericin were still relatively high. When the concentrations of both reached $1.0 \mathrm{mg} / \mathrm{mL}$, their inhibition rates reached $40-45 \%$. After the simulated digestion, the inhibitory activity of the product also increased seven-fold, and the $\mathrm{IC}_{50}$ values of the $\alpha$-amylase inhibitory activity reached $0.2864 \pm 0.05 \mathrm{mg} / \mathrm{mL}$ and $0.371 \pm 0.02 \mathrm{mg} / \mathrm{mL}$, respectively. This shows that after simulated metabolism, whether it is HS or LS and their metabolites, their hypoglycemic activities in vitro are greatly enhanced. Sericin can reduce the solubility of cholesterol in solution. In vitro cell experiments found that sericin can reduce the uptake and utilization of cholesterol by intestinal cells [31]. Determining the uptake of radiolabeled cholesterol in sericin solution in human cloned colon adenocarcinoma cells (Caco-2), Limpeanchob et al. found that sericin levels as low as 25 and $50 \mu \mathrm{g} / \mathrm{mL}$ inhibited the entry of cholesterol into Caco- 2 by $30 \%$ At the same time, it was found that administering sericin can reduce the levels of high density lipoprotein (HDL) and cholesterol (CHOL) in rats with high cholesterol diet, i.e., sericin regulates blood lipid levels in the body by reducing the utilization of cholesterol by intestinal cells and enabling the precipitation of cholesterol [32]. This result is also consistent with the results of our recent hypoglycemic test in diabetic mice and rats using this small-molecular-weight sericin peptide and its hydrolysate [14,33]. After 4 weeks of feeding, this degraded sericin peptide and its hydrolysate could significantly improve the physiological and biochemical indicators of STZ-induced diabetic mice and rats, the abnormal glucose tolerance and insulin tolerance were significantly improved, the serum insulin level was reduced, and insulin resistance decreased whereas insulin sensitivity increased. The content of glycated serum protein (GSP) in serum was significantly reduced, 
and fasting blood glucose was significantly reduced or close to the levels in normal mice, which can improve the activity of serum liver function enzymes and reduce the levels of CHO1, TG (thyroglobulin), HDL, LDL (low-density lipoprotein) and LDH (lactate dehydrogenase), thereby improving blood lipid metabolism. Immunofluorescence staining showed that consuming sericin can improve the abnormal secretion of pancreatic insulin in diabetic rats. Therefore, the oral tests in diabetic mice and rats in vivo and the biological activity tests of digestion products simulated in vitro both showed that LS obtained by calcium hydroxide degumming is digested and absorbed by the stomach and intestines. The smaller molecules of the sericin peptide and its hydrolysates enter the blood to reach various organs, especially the liver. The enhancement of the body's antioxidant effect could reduce the body's oxidative stress response and inflammation, leading to increased serum antioxidant enzymes, improved lipid metabolism, glucose metabolism, and insulin metabolism, finally tending to return blood sugar to normal levels. The above results fully indicate that the antioxidant capacity and ability to inhibit free radicals of sericin and its metabolites in mice contribute significantly to lowering blood sugar levels, whereas their in vitro hypoglycemic activity plays a minor role in lowering blood sugar levels in vivo.

\section{Conclusions}

In this study, both high-temperature and $\mathrm{Ca}(\mathrm{OH})_{2}$-ultrasonic methods were used for degumming the cocoon shells of silkworms to cleanly recover sericin protein. HS and LS (sericins of high and low molecular weight, respectively) were obtained. The two kinds of sericin were processed by in vitro simulated digestion and two metabolites, EHS and ELS, were obtained. By comparing the molecular weight range of sericin and its metabolites by SDS-PAGE, it was found that after simulated digestion, the molecular weights of the two metabolites decreased significantly, indicating that both sericins were efficiently degraded. At the same time, the biological activity of sericin and its metabolites was measured. Compared with HS and LS, the antioxidant activities and glucosidase inhibitory activities of EHS and ELS were significantly enhanced, indicating that HS and LS may be hydrolyzed into smaller molecules, polypeptides, or oligomeric peptides in the body. Regardless of their molecular size, sericins could eliminate free radicals in the body. They could also reduce oxidative stress, inhibit the degradation of carbohydrates by hydrolase, and reduce the damage to the body caused by high sugar levels. In conclusion, the experimental results in this article show that small-molecular-weight sericin with better water solubility has better development potential in functional foods, which can help to lower blood sugar. The next step in our laboratory is to feed the small-molecule sericin and hydrolysate recovered from silk processing as biological drugs to type 2 diabetic rats to explore their hypoglycemic effect and mechanism.

Author Contributions: All authors conducted experiments. Z.-Z.W.: data analysis, writing original draft and editing; Y.-J.W.: data analysis, writing original draft. All authors have read and agreed to the published version of the manuscript. Y.-Q.Z.: conceiving the idea, refining the manuscript, reviewing, and providing funds.

Funding: This study was funded by the China Agriculture Research System (CARS-18-ZJ0502) and the Priority Academic Program Development of Jiangsu Higher Education Institutions (PAPD).

Institutional Review Board Statement: Not applicable.

Informed Consent Statement: Not applicable.

Data Availability Statement: Code and material; The datasets used and/or analyzed during the current study as well as analysis scripts are available from the corresponding author on reasonable request.

Conflicts of Interest: The authors declare no conflict of interests. 


\section{References}

1. Chen, Z.; Yang, S.; He, Y.; Song, C.; Liu, Y. Effect of sericin on diabetic hippocampal growth hormone/insulin-like growth factor 1 axis. Neural Regen. Res. 2013, 8, 1756-1764. [CrossRef]

2. Chen, Z.; He, Y.; Song, C.; Dong, Z.; Su, Z.; Xue, J. Sericin can reduce hippocampal neuronal apoptosis by activating the Akt signal transduction pathway in a rat model of diabetes mellitus. Neural Regen. Res. 2012, 7, 197-201. [CrossRef] [PubMed]

3. Song, C.; Yang, Z.; Zhong, M.; Chen, Z. Sericin protects against diabetes-induced injuries in sciatic nerve and related nerve cells. Neural Regen. Res. 2013, 8, 506-513. [CrossRef]

4. Song, C.-J.; Yang, Z.-J.; Tang, Q.-F.; Chen, Z.-H. Effects of sericin on the testicular growth hormone/insulin-like growth factor-1 axis in a rat model of type 2 diabetes. Int. J. Clin. Exp. Med. 2015, 8, 10411-10419. [PubMed]

5. Ampawong, S.; Isarangkul, D.; Aramwit, P. Sericin ameliorated dysmorphic mitochondria in high-cholesterol diet/streptozotocin rat by antioxidative property. Exp. Biol. Med. 2017, 242, 411-421. [CrossRef] [PubMed]

6. Song, C.; Liu, D.; Yang, S.; Cheng, L.; Xing, E.; Chen, Z. Sericin enhances the insulin-PI3K/AKT signaling pathway in the liver of a type 2 diabetes rat model. Exp. Ther. Med. 2018, 16, 3345-3352. [CrossRef] [PubMed]

7. Zhang, Y.-Q. Applications of natural silk protein sericin in biomaterials. Biotechnol. Adv. 2002, 20, 91-100. [CrossRef]

8. Lamboni, L.; Gauthier, M.; Yang, G.; Wang, Q. Silk sericin: A versatile material for tissue engineering and drug delivery. Biotechnol. Adv. 2015, 33, 1855-1867. [CrossRef] [PubMed]

9. Capar, G.; Aygün, S.; Gecit, M. Treatment of silk production wastewaters by membrane processes for sericin recovery. J. Membr. Sci. 2008, 325, 920-931. [CrossRef]

10. Cao, T.-T.; Zhang, Y.-Q. Processing and characterization of silk sericin from Bombyx mori and its application in biomaterials and biomedicines. Mater. Sci. Eng. C 2016, 61, 940-952. [CrossRef] [PubMed]

11. Cao, T.-T.; Zhou, Z.-Z.; Zhang, Y.-Q. Processing of $\beta$-Glucosidase-Silk Fibroin Nanoparticle Bioconjugates and Their Characteristics. Appl. Biochem. Biotechnol. 2014, 173, 544-551. [CrossRef] [PubMed]

12. Yamazaki, M.; Nakamura, N.; Kurioka, A.; Komatsu, K. Antioxidative activity of ethanolic extracts of cocoon shell. J. Seric. Sci. Jpn. 1999, 68, 167-169. [CrossRef]

13. Wang, H.-Y.; Zhao, J.-G.; Zhang, Y.-Q. The flavonoid-rich ethanolic extract from the green cocoon shell of silkworm has excellent antioxidation, glucosidase inhibition, and cell protective effects in vitro. Food Nutr. Res. 2020, 64, 1-12. [CrossRef] [PubMed]

14. Dong, X.; Zhao, S.-X.; Yin, X.-L.; Wang, H.-Y.; Wei, Z.-G.; Zhang, Y.-Q. Silk sericin has significantly hypoglycaemic effect in type 2 diabetic mice via anti-oxidation and anti-inflammation. Int. J. Biol. Macromol. 2020, 150, 1061-1071. [CrossRef] [PubMed]

15. Kumar, J.P.; Mandal, B.B. Inhibitory role of silk cocoon extract against elastase, hyaluronidase and UV radiation-induced matrix metalloproteinase expression in human dermal fibroblasts and keratinocytes. Photochem. Photobiol. Sci. 2019, 18, 1259-1274. [CrossRef]

16. Liu, S.; You, L.; Zhao, Y.; Chang, X. Hawthorn Polyphenol Extract Inhibits UVB-Induced Skin Photoaging by Regulating MMP Expression and Type I Procollagen Production in Mice. J. Agric. Food Chem. 2018, 66, 8537-8546. [CrossRef]

17. Aramwit, P.; Luplertlop, N.; Kanjanapruthipong, T.; Ampawong, S. Effect of urea-extracted sericin on melanogenesis: Potential applications in post-inflammatory hyperpigmentation. Biol. Res. 2018, 51, 54. [CrossRef]

18. Ono, K.; Takahashi, R.; Ikeda, T.; Mizuguchi, M.; Hamaguchi, T.; Yamada, M. Exogenous amyloidogenic proteins function as seeds in amyloid $\beta$-protein aggregation. Biochim. Biophys. Acta (BBA) Mol. Basis Dis. 2014, 1842, 646-653. [CrossRef]

19. He, H.; Cai, R.; Wang, Y.; Tao, G.; Guo, P.; Zuo, H.; Chen, L.; Liu, X.; Zhao, P.; Xia, Q. Preparation and characterization of silk sericin/PVA blend film with silver nanoparticles for potential antimicrobial application. Int. J. Biol. Macromol. 2017, 104, 457-464. [CrossRef]

20. Cai, R.; Tao, G.; McPhee, D.J.; Song, K.; Zuo, H.; Jiang, W.; Wang, Y. One-Step Synthesis of Silver Nanoparticles on PolydopamineCoated Sericin/Polyvinyl Alcohol Composite Films for Potential Antimicrobial Applications. Molecules 2017, 22, 721. [CrossRef]

21. Wang, Y.-J.; Zhang, Y.-Q. Three-layered sericins around the silk fibroin fiber from Bombyx mori cocoon and their amino acid composition. Adv. Mater. Res. 2011, 175-176, 158-163. [CrossRef]

22. Zhao, Z.-L.; Li, W.-W.; Wang, F.; Zhang, Y.-Q. Using of hydrated lime water as a novel degumming agent of silk and sericin recycling from wastewater. J. Clean. Prod. 2018, 172, 2090-2096. [CrossRef]

23. Zhao, Z.-L.; Zhang, Y.-Q. Greener degumming production of layered sericin peptides from a silkworm cocoon and their physicochemical characteristics and bioactivities in vitro. J. Clean. Prod. 2020, 261, 121080. [CrossRef]

24. Khan, M.R.; Tsukada, M.; Gotoh, Y.; Morikawa, H.; Freddi, G.; Shiozaki, H. Physical properties and dyeability of silk fibers degummed with citric acid. Bioresour. Technol. 2010, 101, 8439-8445. [CrossRef] [PubMed]

25. Djaoudene, O.; Mansinhos, I.; Gonçalves, S.; Jara-Palacios, M.J.; Bey, M.B.; Romano, A. Phenolic profile, antioxidant activity and enzyme inhibitory capacities of fruit and seed extracts from different Algerian cultivars of date (Phoenix dactylifera L.) were affected by in vitro simulated gastrointestinal digestion. S. Afr. J. Bot. 2021, 137, 133-148. [CrossRef]

26. Garrett, D.A.; Failla, M.L.; Sarama, R.J.; Craft, N. Accumulation and retention of micellar $\beta$-carotene and lutein by Caco-2 human intestinal cells. J. Nutr. Biochem. 1999, 10, 573-581. [CrossRef]

27. Wang, H.-Y.; Zhang, Y.-Q. Effect of regeneration of liquid silk fibroin on its structure and characterization. Soft Matter 2013, 9, 138-145. [CrossRef]

28. Wang, H.-Y.; Wang, Y.-J.; Zhou, L.-X.; Zhu, L.; Zhang, Y.-Q. Isolation and bioactivities of a non-sericin component from cocoon shell silk sericin of the silkworm Bombyx mori. Food Funct. 2012, 3, 150-158. [CrossRef] 
29. Olabiyi, A.A.; Smith, Y.R.A.; Babatola, L.J.; Akinyemi, A.J.; Oboh, G. Inhibitory effect of aqueous extract of different parts of Gossypium herbaceum on key enzymes linked with type 2 diabetes and oxidative stress in rat pancreas in vitro. Beni Suef Univ. J. Basic Appl. Sci. 2016, 5, 180-186. [CrossRef]

30. Zhang, M.; Pan, L.J.; Jiang, S.T.; Mo, Y.W. Protective effects of anthocyanins from purple sweet potato on acute carbon tetrachloride-induced oxidative hepatotoxicity fibrosis in mice. Food Agric. Immunol. 2015, 27, 157-170. [CrossRef]

31. Bunarsa, S.; Promphet, P.; Sutheerawattananonda, M.; Kunthalert, D. Hematological assessments of sericin-derived ol-igopeptides in balb/c mice. Acad. J. 2013, 8, 17-21. [CrossRef]

32. Limpeanchob, N.; Trisat, K.; Duangjai, A.; Tiyaboonchai, W.; Pongcharoen, S.; Sutheerawattananonda, M. Sericin Reduces Serum Cholesterol in Rats and Cholesterol Uptake into Caco-2 Cells. J. Agric. Food Chem. 2010, 58, 12519-12522. [CrossRef] [PubMed]

33. Wang, H.-D.; Zhong, Z.-H.; Weng, Y.-J.; Wei, Z.-Z.; Zhang, Y.-Q. Degraded Sericin Significantly Regulates Blood Glucose Levels and Improves Impaired Liver Function in T2D Rats by Reducing Oxidative Stress. Biomolecules 2021, 11, 1255. [CrossRef] 